J. Product. \& Dev., 19(2):199-214(2014)

\title{
VIRULENCE OF ENTOMOPATHOGENIC NEMATODES TO Ceratitis capitata (WIED.) (DIPTERA: TEPHRITIDAE)
}

\author{
S.A. Hammad \\ Department of Plant Protection, Faculty of Agriculture, Al-Azhar \\ University, Cairo, Egypt.
}

\begin{abstract}
The virulence of entomopathogenic nematode species Steinernema carpocapsae (All) and Heterorhabditis bacteriophora (HP88) was determined against the $3^{\text {rd }}$ instar larvae of Ceratitis capitata (Wied.) throughout three tested media under laboratory conditions. Analysis of data revealed that filter paper media has significant effect than another two media. Such effect descendingly arranged follow: filter paper followed by soil and soil with manure, mortality rates were 40.74, 29.63 and 25.37 respectively. S. carpocapsae (All) was the most virulent than $H$. bacteriophora (HP88) at all tested media and concentrations. Mortality rates were $78.14,65.93,53.33,39.26$ and $21.86 \%$ respectively for $S$. Capocapsae (All) while they were 60.74, 52.22, 37.40, 28.52 and $12.52 \%$ respectively, for $H$. bacteriophora (HP88). Lc $c_{50}$ at 72 hours were obtained for the two entomopathogenic nematode species at the three tested media. Temperature influences nematode virulence, the optimum temperature for nematode pathogenicity was $\left(25^{\circ} \mathrm{C}\right)$ then mortality decreased at the lowest $\left(20^{\circ} \mathrm{C}\right)$ and highest $\left(30^{\circ} \mathrm{C}\right)$ in two tested entomopathogenic nematode species.

Results showed that S. carpocapsae (All) and H.bacteriophora (HP88) caused higher mortality in loamy soil than clay or sandy soil. Mortality rates of medfly larvae were reduced in all soil types mixed with cow manure compared with soil without manure.
\end{abstract}

Key words: Virulence, entomopathogenic nematodes, Ceratitis capitata, diptera : tephritidae

\section{INTRODUCTION}

Medfly, Ceratitis capitata (Wiedemann) (Diptera : Tephritidae ) is considered as one of the world's most destructive fruit pests because of its high capability to damage the production, it's global distribution and it's wide range of hosts. 
It causes significant fruit losses worldwide due to damages resulting from their oviposition into fruits and from pulp consumption by their larvae.

Damage occurs because females oviposite in ripening fruit which opens a door for microorganisms, resulting in fruit contamination and decay. It is a major pest capable of infesting many different species of fruits, vegetables and nuts.

Until the end of the 1980's, fruit fly control was based exclusively on chemical control. However due to indiscriminate use of chemical products, problems arisen such as the resurgence of pests, resistant populations, environmental contamination, and residues in the final sales product, which required the adoption of other control practices to fight the pest. This insect is difficult to control with insecticide because larvae develop inside the fruit and move to the soil for pupation. Entomopathogenic nematodes belonging to families steinernematidae and heterorhabditidae are available commercially in many parts of the world to control a number of different soil insect pests (Kaya and Caugler, 1993).

One method of biological control that could be used is the application of entomopathogenic nematodes against alive stages in the soil. (Dolinski and Samuels, 2002). H. bacteriophora was pathogenic against S. littoralis and A. ipsilon larvae as reported by Hammad (1996, 2001).Aggarwal et al. (2014) determined the efficacy and interaction between entomopathogenic nematodes and Bacillus thuringiensis Var. Kurstaki against $2^{\text {nd }}$ and $3^{\text {rd }}$ larval instars of diamondback moth (DBM) Plutellaxylostella under laboratory conditions. Insect larvae were susceptible to nematode infestation. There was no imporovement in the efficacy of the combination treatment over that of nematodes or bacterium when each was used alone. Entomopathogenic nematodes have shown potential as bio-control agents of pests especially those with a soil phase (Georgis and Gaugler, 1991; Alekseev et al., 2006).

Ceratitis capitata spends parts of it's life cycle in the soil, where entomopathogenic nematodes are found (Lindegren et al., 1989 and Gazity et al., 2000). Steinernematid and Heterorhabditid are promising for the control of $C$. capitata, as the pest's behavior of leaving the fruit and penetrating the soil for pupal development allows nematode action.

Studies have indicated that tephritid larvae are susceptible to these nematodes; although pupae are more resistant (Beavers \& Calkins, 1984) $S$. carpocapsae (Mexican isolate) has caused $87 \%$ mortality in C. capitata larvae at doses of up to 500 infective juvenils $/ \mathrm{cm}^{2}$ (Grewal et al., 2001). The pathogenicity of the nematode Heterorhabditis spp. (isolate IBCBn05) has been evaluated against the pre-pupal stages of medfly, and was found to be 
effective at the concentration of 200 infective juveniles/medfly (Almeida et al., 2007).

Therefore, the objective of this study was to examine the virulence of S. carpocapsae (All) and H. bacteriophora (HP88) against the $3^{\text {rd }}$ instar larvae of the medfly $C$. capitata under laboratory conditions. Also, investigating the factors (nematode dose, experimental temperatures, soil types and adding manure with soil) that may affect the susceptibility of the larvae to infection with nematodes.

\section{MATERIALS AND METHODS}

\section{Insect:}

Mediterranean fruit fly, Ceratitiscapitata (Wiedemann) was provided by horticulture insects department, plant protection research institute ARC, Ministry of Agriculture. Insect have been rearing in our laboratory at the department of plant protection, Faculty of Agriculture, AlAzhar University. The colony was stated with pupae and was maintained under controlled conditions $\left(25 \pm 2^{\circ} \mathrm{C}, 70 \pm 5 \% \mathrm{RH}\right)$. After the emergence of pupae flies were provided with water (through apiece of sponge) and food (sugar and enzymatic yeast hydrolysate in ratio 3:1, respectively) (El-Sayed, 1979). The larval diet ingredients (Tanaka et al., 1969) consists of wheat bran $23.5 \%$ Molasses $8.5 \%$, yeast $5.8 \%$, sodium benzoate $0.1 \% \mathrm{HCl} 0.1 \%$ and tap water $58.5 \%$. In the present work, late third instar larvae were collected within two hours after they had exited from the diet to pupate.

\section{Entomopathogenic nematodes:}

Entomopathogenic nematode strains used in the present investigation were $H$. bacteriophora HP88 and $S$. carpocapsae. All obtained from Biological Control Laboratory, Plant Protection Department, National Research Center. The nematodes were reared in Galleria mellonella (L.) (Pyralidae: Lepidoptera) larvae according to procedures in (Wooding and Kaya, 1988). Larvae were starved for several hours before infection. Every ten healthy mature larvae were placed on a filter paper in a Petridish where 1000 of nematode Ijs in $1.5 \mathrm{ml}$ sterilized distilled water was added. The dish was completely dosed. Dishes were kept at $25^{\circ} \mathrm{C} \pm 2$ in an incubator. Two days after inoculation, dead larvae were removed and cadavers were placed on white traps for extraction according to the technique of (White, 1927). The infective juveniles were harvested and stored in sterilized water at $10^{\circ} \mathrm{C}$ for 7-12 days before use (Woodring and Kaya, 1988). Viability of nematodes was determined based on movement as seen under microscopebefore use. 
Pathogenicity of nematodes on $3^{\text {rd }}$ larval instar of C. capitata at different temperatures:

Before the laboratory studies a third medfly larvae were starved for 7 hours prior to experiment. The two nematode species were screened for their virulence against the $3^{\text {rd }}$ instar medfly larvae at three constant temperatures: 20,25 and $30^{\circ} \mathrm{C}$ and $70 \pm 5 \% \mathrm{RH}$. Tests were conducted in conical plastic cups $(6.5 \mathrm{~cm}$ diameter $\mathrm{x} 4.5 \mathrm{~cm}$ lower surface $\mathrm{x} 3 \mathrm{~cm}$ height $)$ with perforated covers lined with moistened filter paper.

For each cup, $1 \mathrm{ml}$ of a suspension containing 750, 1500, 3000, 5000 and 7000 nematodes were applied to the filter paper. Ten larvae were placed in each cup and replicated three times for each concentration. Cups with distilled water free of nematodes used as check ones. Larvae were observed, larval mortality were recorded at 72 hours post treatment.

\section{Influence of soil type and manure on nematode species infectivity to $C$. capitata larvae:}

The two nematode species were laboratory screened for their virulence against the $3^{\text {rd }}$ instarmedfly larvae at $25^{\circ}$ Cand $70 \pm 5 \%$ RH using two methods of application, three different soil types (Clay, Loamy and Sandy). Different types of soil used were obtained from Soils \& Water Resources Department, Faculty of Agriculture, Al-Azhar University. Tests were conducted in conical plastic cups $(6.5 \mathrm{~cm}$ diameter $\mathrm{x} 4.5 \mathrm{~cm}$ lower surface $\mathrm{x}$ $3 \mathrm{~cm}$ height) $40 \mathrm{gm}$ soil was added for each cup. Soil was moistened by atomizer adequate distilled water before inoculation with nematodes. For each cup, $1 \mathrm{ml}$ of a suspension containing 750, 1500, 3000, 5000 and 7000 nematodes was applied to soil. Ten medfly larvae were placed in each cup and replicated three times for each concentration. In another assay, the soil types were substituted by $5 \mathrm{gm}$ of cow manure mixed with the same three soil types. Cups with distilled water or containing clean soil free of nematode were used as check ones. Larvae were observed and larval mortality was recorded at 72 hours post treatment.

\section{Statistical analysis:}

Based on the data obtained, following statistical analysis has been carried out probit analysis (Finney, 1971) and analysis of variance (Three Way ANOVA) (SAS Institute, 2002).

\section{RESULTS}

Under controlled laboratory conditions, the present study demonstrated that the medfly larvae $C$. capitata were susceptible to H.bacteriophora (HP88) and S. carpocapsae (All) as a biological control 
agent. The pathogenicity of these entomopathogenic nematodes were investigated.

\section{Media:}

There was no mortality in the control. Mortality percentage of the third instar larvae of the medfly to these nematodes at five concentrations under three different media are shown in Table (1) in the filter paper assay (irrespective to soil or soil with manure media), analysis of data generally, revealed that the highest mortality in $C$. capitata third larval instar. Amean of 40.74 dead larvae treated with $H$. bacteriophora (HP88) were recorded in filter paper it was followed discendingly by soil (29.63).Significantly efficiency than soil and soil with manure. Descending order filter paper $>$ soil $>$ soil with manure. Showing mortality rate 40.74, 29.63 and 25.37 , respectively.

Steinernema carpocapsae also showed that the same trend but significantly effect filter paper and soil than soil with manure, the percentage mortality rate were $46.30,48.33$ and 34.63 , respectively. On the other hand, $S$. carpocapsae (All) was more efficient than H. bacteriophora (HP88) in all three treatments (filter paper), soil and soil with manure respectively, as shown in Table 1 . Mortality percentages were 46.30 and $40.74,48.33$ and $29.63,34.63$ and 25.37 irrespective to any another factors.

\section{Temperature:}

Temperature pathogenicity relationship showed that there is significant difference in the pathogenicity of the tested entomopathogenic nematode species to the $3^{\text {rd }}$ larval instar of $C$. capitataat the tested temperature as shown in Table 1 . There is difference between mean mortality values caused by $H$. bacteriophora (HP88) due to the difference of temperatures. The higher efficiency was at $25^{\circ} \mathrm{C}$ while lower at $20^{\circ} \mathrm{C}$ and the lowest was at $30^{\circ} \mathrm{C}$. There is a significant deference between the pathogenicity at $25^{\circ} \mathrm{C}$ and $30^{\circ} \mathrm{C}$. Mortality rate were $37.22,33.33$ and 25.19 , respectively. There was no mortality in the control. The pathogenicity of $S$. carpocapsa (All) was the highest at $25^{\circ} \mathrm{C}$ than $30^{\circ} \mathrm{C}$ and $20^{\circ} \mathrm{C}$, mortality percentages were 51.67 , 39.44 and 38.15 respectively. Significant efficiency between the virulence at $25^{\circ} \mathrm{C}$ and both $30^{\circ} \mathrm{C}$ and $20^{\circ} \mathrm{C}$. On the other hand, both H.bacteriophora and S.carpocapsae were more pathogenic at $25^{\circ} \mathrm{C}$ but, $S$. carpocapsae (All) also more virulent than $H$. bacteriophora (HP88) at all tested temperatures, mortality rate were $51.67,37.22$ and $39.44,25.18$ and $38.15,33.33$ at $25^{\circ} \mathrm{C}$, $30^{\circ} \mathrm{C}$ and $20^{\circ} \mathrm{C}$, respectively.

\section{Concentrations:}

The data obtained indicated that percentage of larval mortalities of $C$. capitata increased by increasing the concentrations of the tested nematodes 
(Table 1). The highest concentration $7000 \mathrm{Ijs} / \mathrm{ml}$ caused $78.15 \%$ larval mortality but the lowest concentration $750 \mathrm{Ijs} / \mathrm{ml}$. Cause 21.85 mortality percentage of $S$. carpocapsae (All) on the $3^{\text {rd }}$ larval instar of $C$. capitata treated with the same trend was obtained in case of $H$. bacteriophora, mortality rates ranged between 60.74 and 12.52 at the highest and the lowest concentrations. On the other hand, S. carpocapsae (All) was the most virulent than $H$. bacteriophora in comparison at all concentrations. Mortality rates were $78.14,65.93,53.33,39.26$ and $21.86 \%$, respectively at S. carpocapsae (All), while they were 60.74, 52.22, 37.40, 28.52 and $12.52 \%$, respectively, at $H$. bacteriophora (HP88).

Two entomopathogenic nematode species were selected to determine the median concentrations $\left(\mathrm{LC}_{50}\right)$ under controlled laboratory conditions. The results in Table 2, Figures (1 and 2) presented the $\mathrm{LC}_{50}$ and $\mathrm{LC}_{90}$ for $S$. carpocapsae (All) and $H$. bacteriophora under three tested constant temperatures $20^{\circ} \mathrm{C}, 25^{\circ} \mathrm{C}$ and $30^{\circ} \mathrm{C}$ and laboratory conditions. These results indicated that the $\mathrm{LC}_{50}$ of $H$. bacteriophora (HP88) at $25^{\circ} \mathrm{C}$ was the lowest compare with $20^{\circ} \mathrm{C}$ and $30^{\circ} \mathrm{C}$ (1795.6, 1903.2 and 5656.6), respectively. So that the pathogenicity was the highest at $25^{\circ} \mathrm{C}$.

Table 1: Factorial analysis of different aspects of H.bacteriophora (HP88) and S.carpocapsae (All) on the $3^{\text {rd }}$ medfly larval mortality percentage.

\begin{tabular}{|c|c|c|c|}
\hline Factor & Level & H.bacteriophora & S.carpocapsae \\
\hline \multirow{4}{*}{ Media } & Filter paper & $40.74 \mathrm{a}$ & $46.30 \mathrm{a}$ \\
\hline & Soil & $29.63 \mathrm{~b}$ & $48.33 \mathrm{a}$ \\
\hline & Soil + Manure & $25.37 \mathrm{~b}$ & $34.63 \mathrm{~b}$ \\
\hline & $\mathrm{P}$ & 0.0001 & 0.0001 \\
\hline \multirow{4}{*}{ Temperature } & $20^{\circ} \mathrm{C}$ & $33.33 \mathrm{a}$ & $38.15 \mathrm{~b}$ \\
\hline & $25^{\circ} \mathrm{C}$ & $37.22 \mathrm{a}$ & $51.67 \mathrm{a}$ \\
\hline & $30^{\circ} \mathrm{C}$ & $25.18 \mathrm{~b}$ & $39.44 \mathrm{~b}$ \\
\hline & $\mathbf{P}$ & 0.0001 & 0.0001 \\
\hline \multirow{7}{*}{ Concentrations } & Control & 0.00 & 0.00 \\
\hline & $750 \mathrm{Ijs} / \mathrm{ml}$ & 12.52 & 21.85 \\
\hline & $1500 \mathrm{Ijs} / \mathrm{ml}$ & 28.52 & 39.26 \\
\hline & $3000 \mathrm{Ijs} / \mathrm{ml}$ & 37.41 & 53.33 \\
\hline & $5000 \mathrm{Jjs} / \mathrm{ml}$ & 52.22 & 65.93 \\
\hline & $7000 \mathrm{Ijs} / \mathrm{ml}$ & 60.74 & 78.15 \\
\hline & $\mathbf{P}$ & 0.0001 & 0.0001 \\
\hline
\end{tabular}

Means with the same letter are not significantly different. 
Table 2: Relative efficiency of H. bacteriophora (HP88) and S.carpocapsae (All) at different temperatures using filter paper as media.

\begin{tabular}{|l|c|c|c|c|c|}
\hline Nematodes & Temperature & LC $_{\mathbf{5 0}}$ & $\mathbf{L C}_{\mathbf{9 0}}$ & Slope & Index \\
\hline \multirow{2}{*}{$\begin{array}{l}\text { H.bacteriophora } \\
\text { HP88) }\end{array}$} & $20^{\circ} \mathrm{C}$ & 1903.2 & 11494 & 1.64 & 94.34 \\
\cline { 2 - 6 } & $25^{\circ} \mathrm{C}$ & 1795.6 & 12874 & 1.50 & 100.0 \\
\cline { 2 - 6 } & $30^{\circ} \mathrm{C}$ & 5656.6 & 25898 & 1.94 & 31.74 \\
\hline \multirow{2}{*}{$\begin{array}{l}\text { S.carpocapsae } \\
\text { (All) }\end{array}$} & $20^{\circ} \mathrm{C}$ & 3040.0 & 22812 & 1.46 & 39.71 \\
\cline { 2 - 6 } & $25^{\circ} \mathrm{C}$ & 1207.1 & 4899 & 2.11 & 100.0 \\
\cline { 2 - 6 } & $30^{\circ} \mathrm{C}$ & 2827.4 & 24183 & 1.38 & 42.69 \\
\hline
\end{tabular}

Moreover, S. carpocapsae (All) at $25^{\circ} \mathrm{C}$ was more virulent than $30^{\circ} \mathrm{C}$ and $20^{\circ} \mathrm{C}$ based on $\mathrm{LC}_{50}(1207.1,2827.4$ and 3040.0), respectively. Moreover, the virulence of $S$. carpocapsae (All) was more pathogenic than $H$. bacteriophora. $\mathrm{LC}_{50}$ of them were 1207.1 and 1795.6 at $25^{\circ} \mathrm{C}$, respectively.

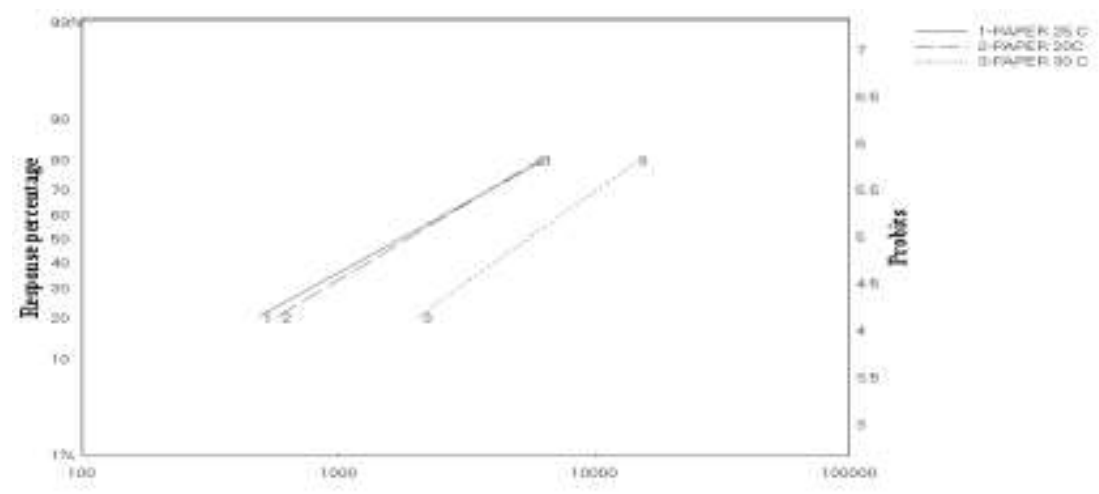

Figure 1: Ld-p line for the mortality of $C$. capitatalarvae at different temperatures using filter paper as media affected by $H$. bacterophora.

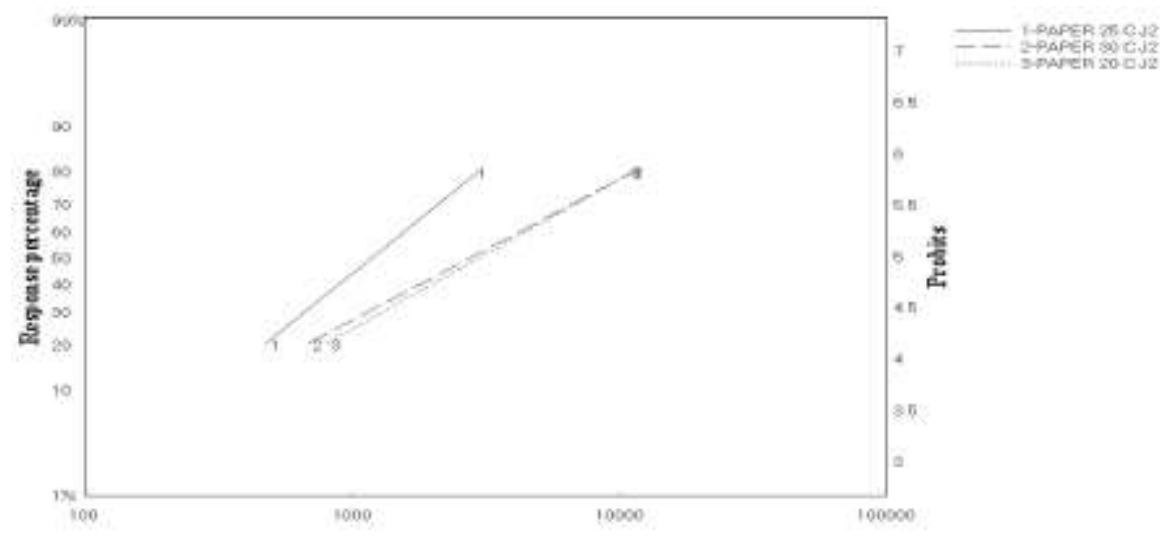

Figure 2: Ld-p line for the mortality of $C$. capitatalarvae at different temperatures using filter paper as media affected by $S$. carpocapsae. 
Results obtained in Table (3), Figures (3 and 4) present the $\mathrm{LC}_{50}$ and $\mathrm{LC}_{90}$ for the two tested entomopathogenic nematode species under controlled laboratory conditions. It is clear that the $3^{\text {rd }}$ larval instar of $C$. capitata was susceptible to applied nematodes at the tested soil types; loamy, clay and sandy. $\mathrm{LC}_{50}$ values indicate that the percentage of mortality was the greatest at loamy soil. $\mathrm{LC}_{50}$ values were 4303.1, 5318.3 and 7250.3 at loamy, clay and sandy soil at $H$. bacteriophora (HP88). The same trend was also shown in $S$. carpocapsae (All). The $\mathrm{LC}_{50}$ values are (1505.4, 1884.0 and 2381.3) at loamy, clay and sand soil respectively. So that the loamy soil was the most susceptible for the highest infectivity of $S$. carpocapsae (All) on C. capitata larvae.

Table 3: Relative efficiency of H.bacteriophora (HP88) and S. carpocapsae (All) at different soil types.

\begin{tabular}{|l|c|c|c|c|c|}
\hline Nematodes & Soil & LC $_{\mathbf{5 0}}$ & LC $_{\mathbf{9 0}}$ & Slope & Index \\
\hline \multirow{2}{*}{$\begin{array}{l}\text { H. bacteriophora } \\
\text { HP88) }\end{array}$} & Loamy & 4303.1 & 42267 & 1.29 & 100.0 \\
\cline { 2 - 6 } & Clay & 5318.3 & 53243 & 1.28 & 80.91 \\
\cline { 2 - 6 } & Sandy & 7250.3 & 77034 & 1.25 & 59.35 \\
\hline \multirow{2}{*}{$\begin{array}{l}\text { S.carpocapsae } \\
\text { All) }\end{array}$} & Loamy & 1505.4 & 7807 & 1.79 & 100.0 \\
\cline { 2 - 6 } & Clay & 1884.0 & 13978 & 1.47 & 79.91 \\
\cline { 2 - 6 } & Sandy & 2381.3 & 20543 & 1.37 & 63.22 \\
\hline
\end{tabular}

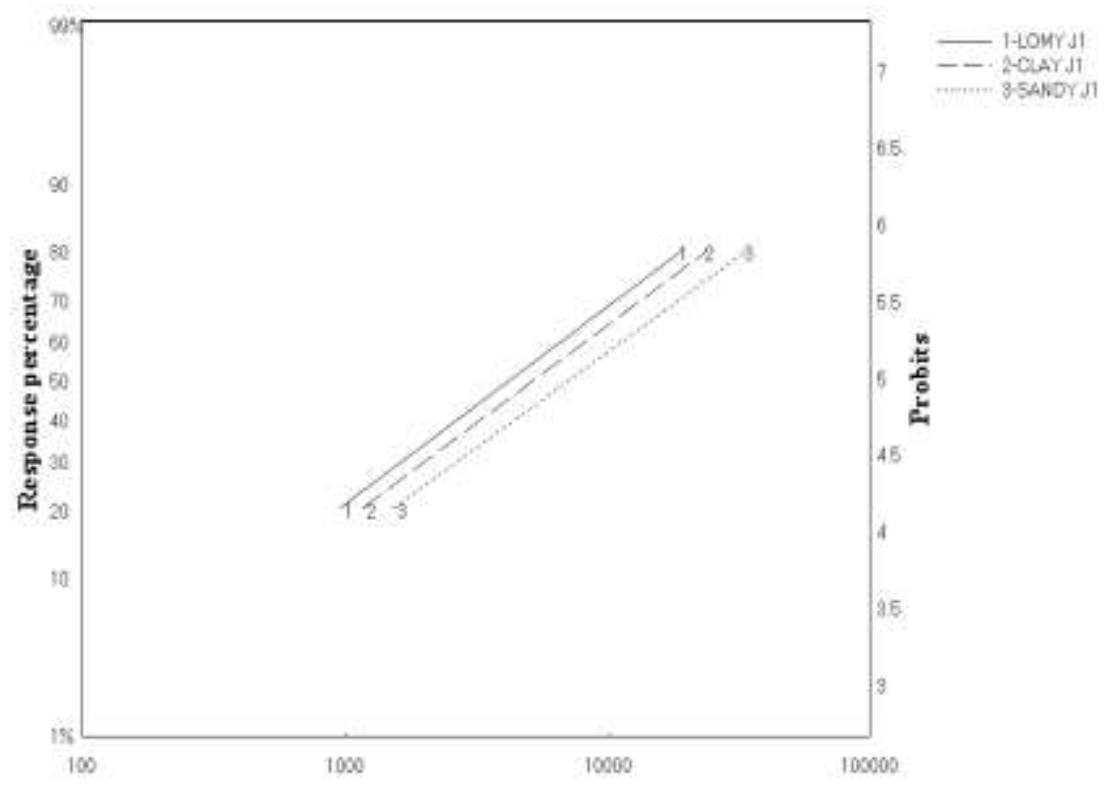

Figure 3: Ld-p line for the mortality of $C$. capitatalarvae at different soil types affected by H. bacterophora. 


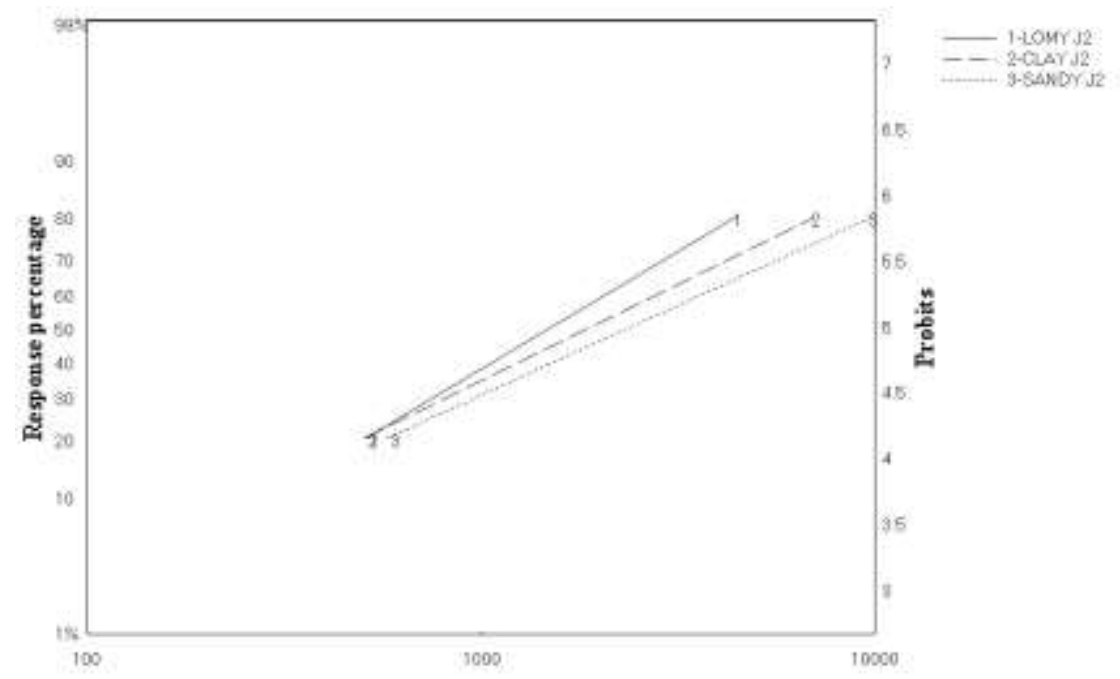

Figure 4: Ld-p line for the mortality of $C$. capitata larvae at different soil types affected by S. carpocapsae.

The results in Table 4, Figures (5 and 6) present the $\mathrm{LC}_{50}$ and $\mathrm{LC}_{90}$ for the two tested entomopathogenic nematode species on $3^{\text {rd }}$ larval instar of C. capitata in three soil types (loamy, sandy, clay) mixed with cow manure under laboratory conditions. It is clear that the loamy soil was the most suitable soil for the pathogenicity of $H$. bacteriophora (HP88) or $S$. carpocapsae (All) to the $C$. capitata larvae. In case of $H$. bacteriophora (HP88) $\mathrm{LC}_{50}$ values were 5442.5, 6968.6 and 7177.6 at loamy soil with manure, sandy soil with manure and clay soil with manure, respectively. Data also, provided that $S$. carpocapsae (All) was most greatest efficiency than $H$. bacteriophora (HP88) at all soil types mixed with cow manure. Values of $\mathrm{LC}_{50}$ were $2519,3794.6$ and 4943.7 at loamy, sandy and clay mixed with manure, respectively.

Table 4: Relative efficiency of H.bacteriophora (HP88) and S.carpocapsae (All) at different soil types with Manure.

\begin{tabular}{|l|c|c|c|c|c|}
\hline Nematodes & Soil with manure & LC $_{\mathbf{5 0}}$ & LC $_{\mathbf{9 0}}$ & Slope & Index \\
\hline \multirow{2}{*}{$\begin{array}{l}\text { H.bacteriophora } \\
\text { HP88) }\end{array}$} & Loamy & 5442.5 & 52361 & 1.30 & 100.0 \\
\cline { 2 - 6 } & Sandy & 6968.6 & 59584 & 1.38 & 78.10 \\
\cline { 2 - 6 } & Clay & 7177.6 & 38954 & 1.75 & 75.83 \\
\hline \multirow{2}{*}{$\begin{array}{l}\text { S.carpocapsae } \\
\text { (All) }\end{array}$} & Loamy & 2519.0 & 24580 & 1.30 & 100.0 \\
\cline { 2 - 6 } & Sandy & 3794.6 & 20371 & 1.76 & 66.38 \\
\cline { 2 - 6 } & Clay & 4943.7 & 22734 & 1.93 & 50.95 \\
\hline
\end{tabular}




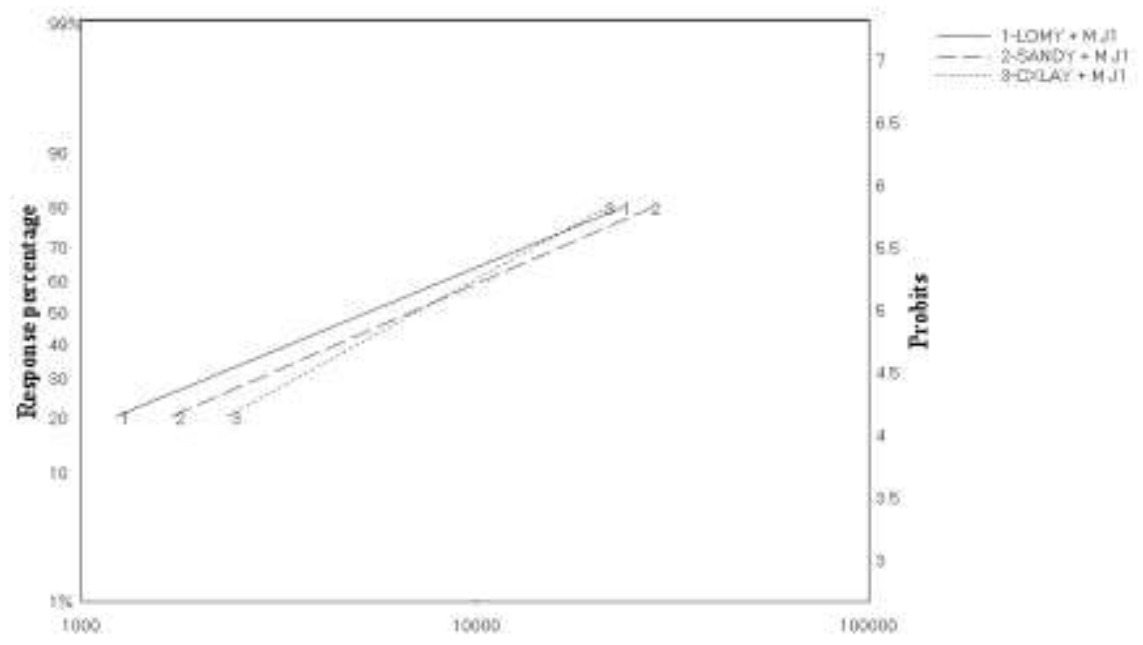

Figure 5: Ld-p line for the mortality of $C$. capitatalarvae at different soil types with manure affected by $H$. bacterophora.

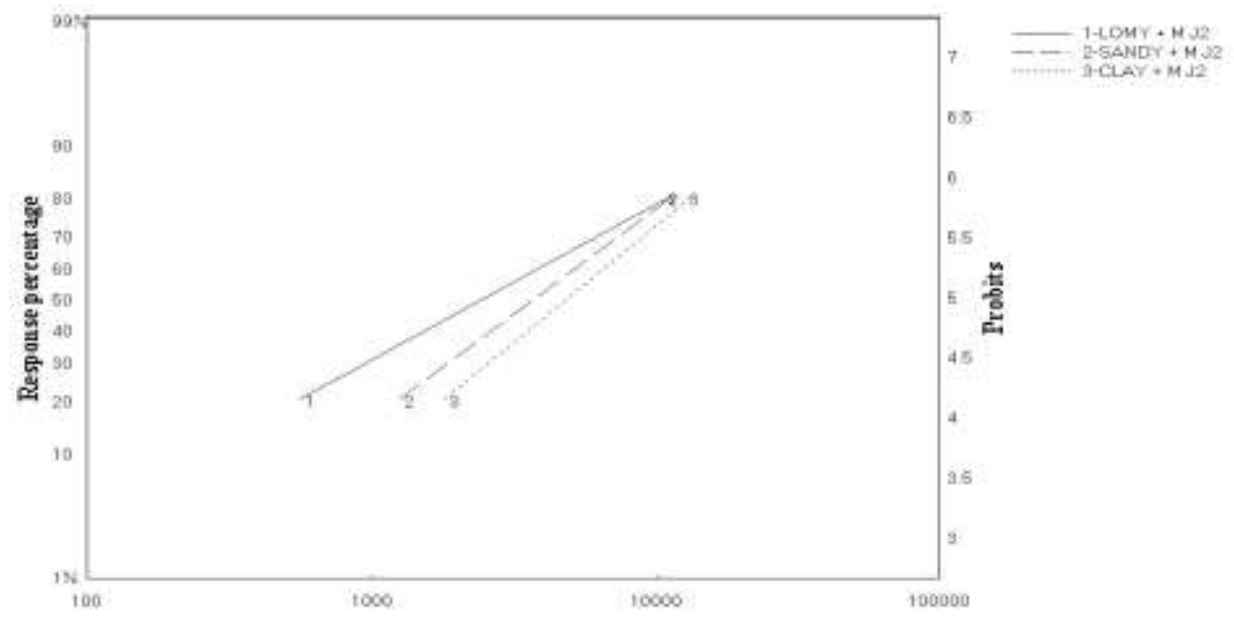

Figure 6: Ld-p line for the mortality of $C$. capitata larvae at different soil types with manure affected by $S$. carpocapsae.

\section{DISCUSSION}

Laboratory studies of entomopathogenic nematode species in Petridish assays at different temperatures, soil types and soil with cow manure generally, showed that $S$. carpocapsae (All) tested were more virulent to medfly larvae than $H$. bacteriophora (HP88). Irrespective to other studying factors Petridish assays with these species supported this result and indicate 
that both $S$. carpocapsae (All) and H. bacteriophora (HP88) were pathogenic and killing the target insect. The greatest larval mortality was obtained for nematode concentration of $7000 \mathrm{Ijs} / \mathrm{ml}$. These result demonstrated the ability of this nematode to find and kill medfly larvae at three different media, petridish assays at different temperatures, soil types and soil with cow manure. Overview, higher mortality rates and $\mathrm{LC}_{50}$ were obtained with filter paper than other media.

Firstly, temperature has been reported as an important environmental factor in survival, mortality, infection, development and reproduction of entomopathogenic nematodes (Poinar, 1979).In the present investigation, mortality rates of $C$. capitata larvae were directly correlated with the exposure temperatures, the optimum temperatures for nematode pathogenicity was $25^{\circ} \mathrm{C}$ then mortality decreased at the lowest $\left(20^{\circ} \mathrm{C}\right)$ and highest temperature $\left(30^{\circ} \mathrm{C}\right.$ ) (Grewal et al., 1993) reported that maximum penetration of Galleria mellonella L. larvae by $S$. carpocapsae was at $24^{\circ} \mathrm{C}$, with reduced penetration occurring at 30 and $35^{\circ} \mathrm{C}$. Hammad and AbdelHamid (2007) reported that housefly larvae were susceptible to the entomopathogenic nematodes at $25^{\circ} \mathrm{C}$. Temperature is the most influential environmental factor, which has great biological significance. Temperature influences nematode mobility, reproduction and development (Mason \& Hominik, 1995). In another study, Shapiro-Ilan et al., (2002) observed that temperature limits the virulence of steinernematids by its influence on nematode activity, bacterial symbiont or both. Mahar et al., (2005) found that the maximum number of S.carpocapsae was produced in the vine weevil larvae Otiorhynchussulcatus F. at $25^{\circ} \mathrm{C}$. The present study demonstrated that $S$. carpocapsae (All) was more efficient than $H$. bacteriophora with $78.15 \%$ and $60.74 \%$ mortality, respectively. The higher efficiency of $S$. carpocapsae at higher temperatures has already been reported (Grewalet al., 1994). Several studies have demonstrated the influence of temperature on the infectivity of entomopathogenic nematodes (El-Sadawy, 2001; Hazir et al., 2001; Ebssa et al., 2003 and Subramanian \& Senthamizh, 2004). Hussainiet al., (2005) also observed a direct relationship between lethal time and temperature. These results indicate that thisentomopathogenic nematodes can be used to control insect pests that occur in tropical climate regions.

The second part of our experiment was carried out to determine the effects of soil type on the pathogenicity of entomopathogenic nematodes against medfly larvae. Both $S$. carpocapsae and $H$. bacteriophora caused different levels of mortality on larvae of $C$. capitatain all tested soil types. The reason for the efficacy of nematodes in all soils might be due to the 
small size of test containers, and consequently the shorter distance which nematodes much move to reach the host insect. The results showed that $S$. carpocapsae (All) and H. bacteriophora (HP88) in loamy soil caused higher mortality than clay or sandy soils. This observation is consistent with early reports that showed infectivity of $S$. carpocapsae and $H$. bacteriophora were higher in lighter soils (Kunget al., 1990; Choo and Kaya, 1991). Mortality rates of medfly larvae were reduced in all soil types with cow manure compared with soil without manure. The decrease of the entomopathogenic nematode pathogenicity may be due to that the increase of organic matter not suitable for the activity of nematodes. Our results appear to differ from those of Bednarek and Gaugler (1997) who found that $S$. Feltiae populations actually increased with the addition of manure to soils. However, studies of Shapiro et al., (1996) supported our result; they found that manure reduced nematode virulence when added to soil as a fertilizer. The high efficiency of $S$. carpocapsae (All) on $C$. capitata larvae could be related to the relatively small size of their infective juveniles, ranging between 438-650 $\mu \mathrm{m}$. (Adams \& Naguyen, 2002) thus facilitating the penetration mode of the steinernematids, which take place through the natural openings of the host (Spiracles, mouth and anus). Most $C$. capitata larvae exposed to the nematode died during the pupal stage. This fact was also observed by Rohde et al., (2010) who studying the susceptibility of $C$. capitata, larvae to the entomopathogen, and Yee \& Lacy (2003) obtained results showed that both S. carpocapsae (All) and H. bacteriophora (HP88) caused mortality on $C$. capitata larvae at all applied concentrations, except in the control treatment. Data also indicate that the higher nematode inoculums levels. However, caused higher mortality than the lower levels.

In brief, our results showed that entomopathogenic nematodes were pathogenic against $3^{\text {rd }}$ larval instar of $C$. capitata the virulence of $S$. carpocapsae (All) was more than H. bacteriophora (HP88). Results also proved that nematode species, concentration, temperature, soil type or soil with manure were significantly affected mortality of medfly larvae under experimental conditions. Further studies are still required to define application strategies for these entomopathogenic nematodes in order to control this insect pest.

\section{CONCLUSION}

The tested entomopathogenic nematode species $S$. capocapsae (All) and $H$. bacteriophora (HP88) were pathogenic to $3^{\text {rd }}$ instar larvae of $C$. capitata. At all three tested media and concentrations, $S$. capocapsae (All) more virulent than $H$. bacteriophora (HP88). The optimum temperature for 
nematode pathogenicity was $25^{\circ} \mathrm{C}$. Loamy soil was suitable for the pathogenicity than clay or sandy soil. Mortality rates of medfly larvae were reduced in all tested soil types with manure compared with soil without manure.

\section{REFERENCES}

Adams, B. and K.B. Nguyen (2002): Taxonomy and systematic In: Gougler, R. (Org.) Entomopathogenic nematology. Walling ford: CABI Publishing, 1-28.

Aggarwal Naveen, Neetan, Kour Gurmeet and Mandadi Nagesh (2014): Efficacy of entomopathogenic nematodes and Bacillus thuringiensis against diamondback moth Plutellaxylostella (L.). J. Res., 51(2): 136-141.

Alekseev, E., I. Glazer and M. Samish (2006): Effect of soil texture and moisture on Entomopathogenic nematodes against female Boophilus annulatus ticks. Bio Control., 51: 507-518.

Almeida, J.E.M., A. Batista, F.C. Oliveira and A. Raga (2007): Pathogenicity of the entomopathogenic fungi and nematode on medfly Ceratitiscapitata (Wied .) (Diptera:Tephritidae ). Bioassays, 2: 1-7.

Beavers, J.B. and C.O. Calkins (1984): Susceptibility of Anastrepha suspense (Diptera:Tephritidae) to Steinernematid and Heterorhabidit nematodes in laboratory studies. Environ. Entomol., 13: 137-139.

Bednarek, A.J. and R. Gaugler (1997): Compatibility of soil amendments with entomopathogenic nematodes. J. Nematol., 29: 220-227.

Choo, H.Y. and H.K. Kaya (1991): Influence of soil texture and presence of Roots on host finding by H.bacteriophora. J. Invertebrate Pathology, 58: 279-280.

Dolinski, C.M. and R.I. Samuels (2002): Comparative efficiency of different species of entomopathogenic nematodes for the control of guava weevil Conotracheluspsidii (Coleoptera: Curculionidae), in: Onstad, D. (Ed.), Proc. Soc. Invertebr. Pathol. Annual Meeting, 35: 54-55.Fozde Iguacu, PR, Brazil.

Ebssa, L., C. Borgemeister and H.M. Poehling (2003): Effects of host density and temperature on the efficacy of entomogenic nematodes for the control of western flower thrips (Frankliniellaoccidentalis). DGaaENachrichten, 17: 25-26.

El-Sadawy, H.A. (2001): Effect of temperature and soil moisture on the infectivity of some entomopathogenic nematodes against larvae of the rice moth and flesh fly. International J. Nematol., 11: 58-62.

El-Sayed, A.I.H. (1979): Biotic potential of Ceratitiscapitata (Wied.) as influenced by the type of diet. M. Sc. Thesis, Fac. of Agric. Zagazig Univ. 
Finney, D.J. (1971): "Probit Analysis" Cabridge University Press, Cambridge, UK. $3^{\text {rd }}$.pp. 333.

Gazity, Rossler and Y. Glazer (2000): Evaluation of entomopathogenic nematodes for the control of Mediterranean fruit fly (Diptera:Tephritidae). Biocontrol Sci. and Technol., 10: 157-164.

Georgis, R. and R. Gaugler (1991): Predictability in biological control using entomopathogenic nematodes, J. Eco. Entomol., 84: 713-720.

Grewal, P.S., E.A. B. De Nardo and M.M. Aguillera (2001): Entomopathogenic nematodes: potential for exploration and use in south America. Neotrop. Entomol., 30: 191-205.

Grewal, P.S., R. Gaugler, H.K. Kaya and M. Wusaty (1993): Infectivity of the entomopathogenic nematodes $S$. scapterisci (Nematode: Steinernematidae). J. Insect Pathol., 62: 22-28.

Grewals, Selvans S. and R. GAUGLER (1994): Thermal adaptation of entomopathogenic nematodes: niche breadth for infection, establishment and reproduction, J. Thermal Biol., 19: 245-253.

Hammad, S.A.M. (1996): Studies on the effect of some pathogenic organisms on insect pests. (M. Sc. Fac. Agric., Al-Azhar Univ., p. 110).

Hammad, S.A.M. (2001): Studies on the biological control of some insect pests of berseem using entomopathogenic nematodes. Ph. D. Thesis, Fac. Agric., Al-Azhar Univ., p. 189.

Hammad, S.A.M. and Y.M. Abdel-Hamid (2007): Factors affecting susceptibility of the housefly larvae to infection with two Entomopathogenic nematodes under laboratory conditions. Ain Shams Science Bulletin, 45: 43-55.

Hazirs, Stock, S.P.; H.K. Kaya; A.M. Kappenhofer and N. Keskin (2001): Developmental temperature effects on five geographic isolates of the entomopathogenic nematode $S$. feltiae (Nematoda: Steinernematidae). (J. Invertebr. Pathol., 77: 243-250.

Hussaini, S.S.; V. Shakeela and M.H. Dar (2005): Influence of temperature of infectivity of entomopathogenic nematodes against black cutworm, Agrotisipsilon (Hufnage) and greater wax moth Galleria mollonella (Linnaeus) Larvae. J. Biol. Control, 19: 51-57.

Kaya, H.K and R.Gaugler (1993): Entomopathogenic nematodes. Annual Review of Entomology, 38: 181-206.

Kaya, H.K. (1990): Soil ecology, pp. 93-115. In entomopathogenic nematodes in biological control (R. Gaugler and H.K. Kaya, eds.) CRC Press, Boca Raton, Florida.

Kung, S.P.; R. Gaugler and H.K. Kaya (1990): Soil type and entomopathogenic nematode persistence. J. Invertebrate Pathology, 55: 401-406. 
Lindegren, J.E.; T.T. Wang and D.O. Mcinnis (1989): Response of Mediterranean fruit fly (Diptera :Tephritidae) to the entomogenous nematode S.feltiae in field tests in Hawaii. Environ. Entomol., 19: 383-386.

Mahar, A.N.; D.A. Darban; A.G. Larjar; M. Munir; N.D. Jan and S.R. Gowen (2005): Influences of temperature on the production and infectivity of entomopathogenic nematodes against larvae and pupae of vine weevil Oitorhynchussulcatus. (Coleoptera: Curculionidae). J. Entomol., 2: 92-96.

Mason, J.M. and W.M. Hominik (1995): The effect of temperature on infection, development and reproduction of Heterorhabditids. $J$. Heleminthol., 69: 337-345.

Poinar, G.O., JR. (1979): Nematodes for biological control of insects. CRC press, Boca Raton, FL.

Rohde, C.; A. Moinoyr; M.A. Silve; F.D. Carvalho and C.S. Ferreira (2010): Influence of soil temperature and moisture on the infectivity of entomopathogenic nematodes (Rhabditida: Heterorhabiditidae steinernematidae /against larvae of Ceratitiscapitata (Wiedemann) (Diptera: Tephritidae). Neotropical Entomology, 39(4): 608-611.

SAS Institute (2002): Users manual version 6.0. SAS Institute. Cart, NC.

Shapiro, D.I.; G.L. Tylka and L.C. Lewis (1996): Effects of fertilizers on virulence of Steinernemacarpocapsae. Appl. Soil Ecol., 3: 27-34.

Shapiro-Ilan, D.I.; D.H. Gouge and A.M. Koppenhofer (2002): Factor affecting commercial success: Case studies in cotton, turf and citrus, In: Gaugler, R. (ed.), entomopathogenic nematology, p. 335. CABI Publication, CAB International, Wallingford, Oxon, UK.

Subramanian, S. and K. Senthamizh (2004): Effects of moisture on the efficacy of nematodes. Current Nematol. 15: 65-67.

Tanaka, N., L.F. Steiner, K. Ohinata and R. Okamoto (1969): Low-cost larval rearing production of oriental and Mediterranean fruit flies. (J. Econ. Entomol., 62: 697-968).

White, G.F. (1927): A method for obtaining infective nematode larvae from culture. Science, Washington, DC, 66: 320-333.

Woodring, J.L. and H.K. Kaya (1988): Steinernematid and heterorhabditid nematodes. A Handbook of Biology and techniques. Southern Coop. Ser. Bull. 331. Arkansas Agric. Exp. Fayetteville, AR.

Yee, W.L. and L.A. Lacey (2003): Stage-Specific mortality of Rhagoletis indifference (Diptera :Tephritidae) exposed to three species of steinernema nematodes. Biological Control, 27(3): 349-356. 


\title{
تأثير النيماتودا الممرضة للحشرات على ذبابة الفاكهة
}

\author{
سعيد عبدالعليم حماد \\ قسم وقاية النبات ، كلية الزر اعة، جامعة الأزهر، القاهرة ـ مصر
}

تم تقدير فاعلية إثنتين من أنواع الديدان الخيطية الممرضة للحشرات شتنبيرنبيا

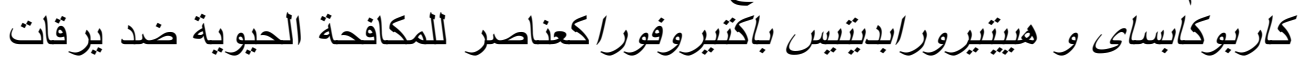

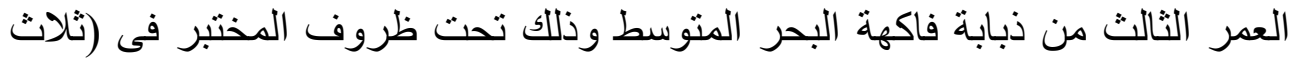

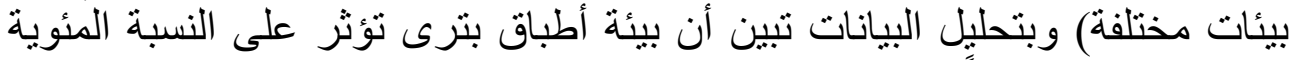

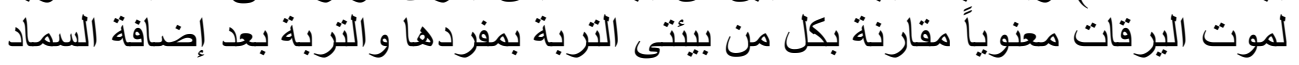

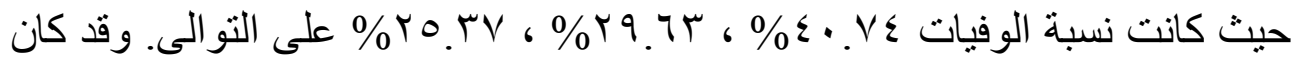

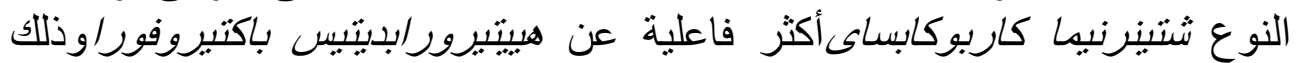

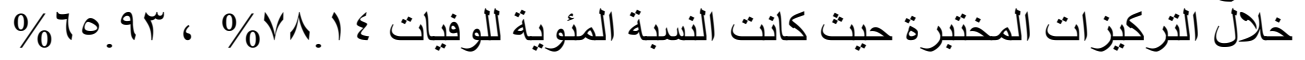

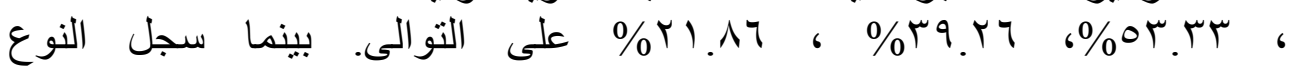

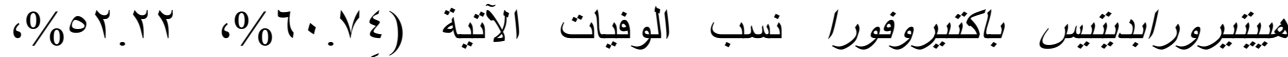

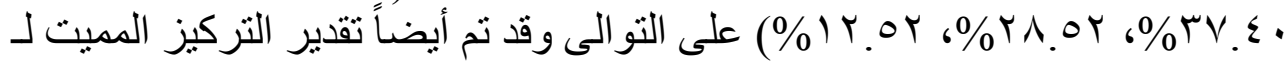

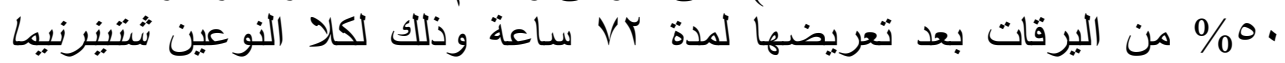

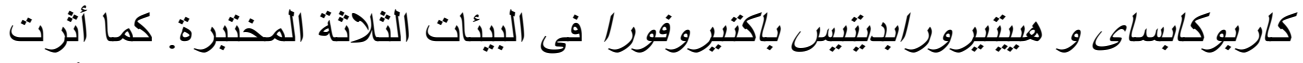

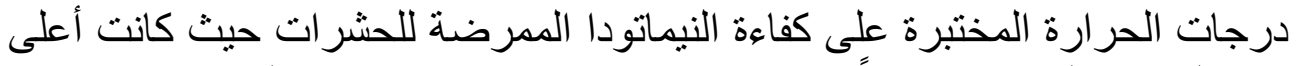

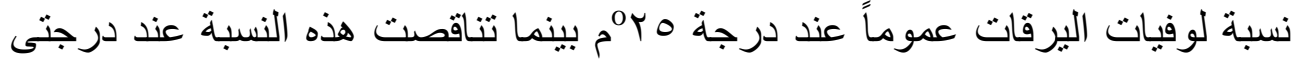

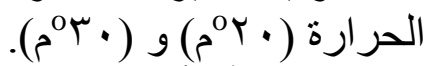

التوصبة: أوضحت النتائج أن التربة الصفر اء الخفيفة أفضل من التربة الطينية

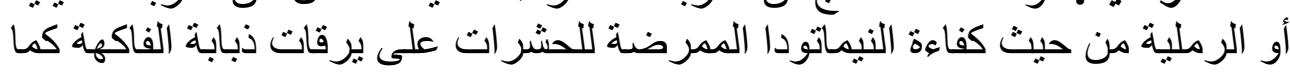

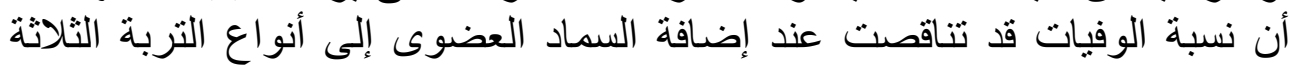

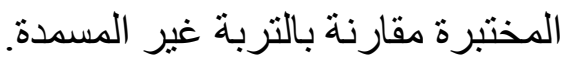

